\title{
Hubungan penerapan metode pembelajaran Project Based Learning berbasis GRASPS berbantuan modul digital dan hasil belajar siswa pada mata pelajaran produktif Multimedia di SMKN 1 Amuntai
}

\author{
Nur Amalinda1, Wahyu Sakti Gunawan Irianto ${ }^{2}$, Heru Wahyu Herwanto ${ }^{3}$ \\ 1. Universitas Negeri Malang, Indonesia | nur.amalinda@gmail.com \\ 2. Universitas Negeri Malang, Indonesia | iriantowsg@yahoo.com \\ 3. Universitas Negeri Malang, Indonesia | heru_wh@um.ac.id
}

\begin{abstract}
Abstrak
Di SMKN 1 Amuntai Matapelajaran Desain Multimedia merupakan salah satu matapelajaran wajib yang harus ditempuh siswa kelas XII program keahlian Multimedia. Penelitian ini menggunakan pendekatan kuantitatif dengan jenis penelitian korelasional yang memiliki tujuan untuk mengetahui hubungan penerapan metode pembelajaran Project Based Learning berbasis GRASPS berbantu modul digital dengan hasil belajar siswa. Populasi yang digunakan dalam penelitian ini adalah siswa kelas XII Multimedia SMK Negeri 1 Amuntai yang berjumlah 80 siswa. Sampel dalam penelitian ini adalah 66 sampel yang diberi perlakuan penerapan Metode Pembelajaran Project Based Learning Berbasis GRASPS berbantu Modul Digital. Hasil belajar pada penelitian ini diukur melalui nilai post-test siswa. Uji Instrumen dilakukan kepada 14 responden diluar sampel. Uji instrumen data yang digunakan adalah validitas dan reliabilitas. Uji pra syarat analisis yang digunakan adalah uji normalitas, linearitas dan homogenitas. Analisis data yang digunakan adalah metode statistik parametris. Uji hipotesis dalam penelitian ini menggunakan korelasi product moment yang digunakan untuk mencari hubungan antar variabel dan menggunkan korelasi regresi linear sederhana untuk mengetahui apakah hubungan tersebut positif atau negatif. Hasil dari penelitian ini menyatakan bahwa terdapat hubungan yang signifikan antara penerapan Metode Pembelajaran Project Based Learning Berbasis GRASPS berbantuan Modul Digital dan Hasil Belajar Siswa pada Matapelajaran Produktif Multimedia di SMKN 1 Amuntai.

Hasil dari penelitian ini menyatakan bahwa terdapat hubungan yang signifikan antara penerapan Metode Pembelajaran Project Based Learning Berbasis GRASPS berbantuan Modul Digital dan Hasil Belajar Siswa pada Matapelajaran Produktif Multimedia di SMKN 1 Amuntai.
\end{abstract}

Kata Kunci

Project Based Learning, GRASPS, Hasil belajar

TEKNO Vol. 28 Issue 1, p61-77 | Jurusan Teknik Elektro, Universitas Negeri Malang, Indonesia | Maret 2018 Nur Amalianda, Wahyu Sakti G. Irianto, Heru Wahyu Herwanto | Hubungan penerapan metode pembelajaran... 


\section{TEKNO Jurnal Teknologi Elektro dan Kejuruan}

http://journal2.um.ac.id/index.php/tekno | ISSN 1693-8739

\section{Pendahuluan}

Mata pelajaran Desain Multimedia Interaktif di SMK Negeri 1 Amuntai merupakan salah satu matapelajaran wajib yang harus ditempuh siswa kelas XII program keahlian Multimedia. Secara umum materi yang disampaikan adalah materi yang membutuhkan gambaran dengan cara praktik kerja yang bertujuan untuk meningkatkan pemahaman dan minat belajar siswa karena siswa SMK lebih tertarik pembelajaran praktik dari pada pembelajaran teori. Sebagai salah satu matapelajaran wajib yang di dalamnya terdapat beberapa kompetensi yang harus dicapai oleh siswa, maka matapelajaran tersebut diajarkan pada siswa kelas XII jurusan Multimedia di SMK Negeri 1 Amuntai.

Salah satu hal yang penting diperhatikan oleh seorang pendidik dalam proses pembelajaran adalah penggunaan metode pembelajaran. Keberhasilan dari suatu pembelajaran dapat diukur dari ketepatan pendidik dalam menggunakan metode sesuai dengan materi, waktu, dan tujuan yang hendak dicapai dari proses pembelajaran tersebut (Suyatno, 2009: 26). Ketepatan dalam menentukan metode juga tidak terlepas dari teknik pembelajaran yang dipilih, karena dalam pelaksanaanya metode dan teknik/tipe pembelajaran saling berkaitan. Dengan kata lain setiap metode memiliki berbagai macam teknik dalam mencapai tujuan pembelajaran sesuai dengan cara belajar yang telah ditentukan. Kualitas dari pendidikan yang dihasilkan, bermula dari bagaimana hasil belajar yang dicapai oleh siswa dalam pembelajarannya. Hasil wawancara dengan guru matapelajaran Desain Multimedia Interaktif, metode belajar yang digunakan saat ini adalah metode Project Based Learning berbasis GRASPS.

Hasil observasi pada penerapan metode PjBL berbasis GRASPS disekolah terdapat beberapa poin yang belum tercapai oleh siswa diantaranya (Situation, Product, and Standart). Situation pada penerapannya berupa tantangan yang akan di berikan kepada siswa, Product berupa sebuah alat atau proyek yang di hasilkan, sedangkan Standart menyatakan bagaimana hasil belajar siswa dinilai. Masalah tersebut mempengaruhi hasil belajar siswa sehingga perlu adanya perbaikan penerapan metode PjBL berbasis GRASPS agar semua elemen GRASPS dapat terpenuhi yang mengarah pada peningkatan hasil belajar. Perbaikan metode Pjbl berbasis GRASPS pada pembelajaran praktikum dilakukan karena metode tersebut sudah menerapkan authentic assessment dimana siswa ditempatkan kedalam skenario dunia nyata, sehingga menghasilkan artefak yang menggambarkan isi pembelajaran dan apa yang mungkin siswa butuhkan untuk menghasilkan sebuah proyek dalam keadaan yang sebenarnya.

Selain ketepatan dalam menentukan metode pembelajaran, sumber belajar juga berperan sebagai acuan siswa dalam belajar. Disekolah saat ini belum ada sumber belajar yang relevan untuk digunakan siswa dalam belajar berdasarkan hasil observasi yang telah dilakukan. Sumber belajar siswa hanya didapat dari Guru dan sumber-sumber yang kurang jelas diinternet. Berdasarkan permasalahan yang timbul di SMKN 1 Amuntai jurusan Multimedia pada matapelajaran Desain Multimedia Intraktif kelas XII, maka perlu pengembangan Modul Digital sebagai sumber belajar utama sekaligus menarik minat siswa dalam belajar yang 


\section{TEKNO Jurnal Teknologi Elektro dan Kejuruan}

http://journal2.um.ac.id/index.php/tekno | ISSN 1693-8739

dikombinasikan dengan metode Project Based Learning berbasis GRASPS yang telah disempurnakan (semua elemen GRASPS terpenuhi).

Penelitian terdahulu menunjukkan bahwa hasil belajar dengan menerpakan metode Project Based Learning berbasis GRASPS mengalami peningkatan, namun belum diketahui hubungannya dengan Hasil Belajar jika berbantu Modul Digital pada matapelajaran Desain Multimedia Interaktif. Oleh karena itu, penulis tertarik untuk melakukan penelitian dengan judul "Hubungan yang signifikan antara Penerapan Metode Pembelajaran Project Based Learning Berbasis GRASPS berbantu Modul Digital dengan Hasil Belajar Siswa pada Matapelajaran Produktif Multimedia di SMKN 1 Amuntai".

Tujuan dari penelitian ini adalah" Mengetahui Hubungan yang signifikan antara Penerapan Metode Project Based Learning berbasis GRASPS berbantu Modul Digital dengan Hasil Belajar Siswa pada Matapelajaran Produktif Multimedia di SMKN 1 Amuntai".

Pembelajaran suatu proses interaksi peserta didik dengan pendidik dan sumber belajar pada suatu lingkungan belajar agar dapat terjadi pemerolehan ilmu dan pengetahuan, serta pembentukan sikap dan kepercayaan pada peserta didik (Amri, 2013:34).

Project Based Learning atau pembelajaran berbasis proyek merupakan model pembelajaran yang berpusat pada siswa untuk melakukan suatu investigasi yang mendalam terhadap suatu topik. Di dalam PjBL proyek dilakukan secara kolaboratif dan inovatif yang berfokus pada pemecahan masalah yang berhubungan dengan kehidupan siswa atau masyarakat (Santyasa, 2006).

GRASPS metode pembelajaran yang menerapkan Authentic Assesment. GRASPS ini adalah: (1) Goal, merupakan tujuan atau aksi yang siswa akan di lakukan dalam skenario (2) Role, yaitu peran siswa dalam skenario (3) Audience, yaitu lingkungan yang nantinya akan berhubungan dengan peran siswa dalam skenario (4) Situation, yaitu tantangan dan detail suasana atau rangkaian kegiatan yang dilakukan dalam skenario (5) Product, yaitu hasil dari aktifitas siswa pembelajaran atau selama menjalankan skenario (6) Standards, menyatakan bagaimana tugas ini akan dinilai, dengan kriteria apa produk tersebut akan dinilai dan apa saja indikator kesuksesannya.

Modul Digital adalah penyajian bahan ajar dalam format digital salah satunya adalah e-book. Buku elektronik atau yang biasa kita kenal dengan istilah e-book merupakan tampilan informasi atau naskah dalam format buku yang direkam secara elektronik dengan menggunakan hardisk, disket, CD, atau flash disk dan dapat dibuka dan dibaca dengan menggunakan komputer atau alat pembaca buku elektronik (e-book viewer atau e-book reader).

Hasil belajar merupakan bagian terpenting dalam pembelajaran. Adapun menurut (Sudjana, 2009: 3) mendefinisikan hasil belajar siswa pada hakikatnya adalah perubahan tingkah laku sebagai hasil belajar dalam pengertian yang lebih luas mencakup bidang kognitif, afektif, dan psikomotorik. 


\section{TEKNO Jumal Teknologi Eektro dan Kejuruan}

http://journal2.um.ac.id/index.php/tekno | ISSN 1693-8739

\section{Metode}

Penelitian ini menggunakan pendekatan kuantitatif dengan jenis penelitian korelasional yang memiliki tujuan untuk mengetahui hubungan metode pembelajaran Project Based Learning berbasis GRASPS dan media pembelajaran modul digital terhadap hasil belajar siswa.

Rancangan penelitian ini menggunakan dua variabel yaitu satu variabel independen dan satu variabel dependen. Metode pembelajaran Project Based Learning berbasis GRASPS dan media pembelajaran modul digital $(X)$ tergolong dalam variabel independen, sedangkan hasil belajar (Y) pada mata pelajaran produktif multimedia masuk dalam variabel dependen.

Populasi adalah wilayah generalisasi yang terdiri atas: obyek/subyek yang mempunyai kualitas dan karakteristik tertentu yang ditetapkan oleh peneliti untuk dipelajari dan kemudian ditarik kesimpulannya (Sugiyono,2015:117).

Populasi yang digunakan dalam penelitian ini adalah siswa kelas XII Multimedia SMK Negeri 1 Amuntai yang berjumlah 80 siswa. Penentuan populasi siswa kelas XII Multimedia SMK Negeri 1 Amuntai didasari karena mata pelajaran produktif multimedia khususnya desain multimedia interaktif adalah mata pelajaran yang sangat penting untuk siswa pahami dengan baik dan benar, dari persiapan membuat produk, langkah-langkah, dan hasil akhir produk yang berkualitas dan sesuai standart harus dipahami dan dimengerti oleh siswa, dikarenakan mata pelajaran ini juga yang akan menjadi sebuah mata pelajaran yang akan di ujian nasional (UN). Hasil dari populasi kelas dapat dilihat pada Tabel 1 sebagai berikut:

Tabel 1. Populasi Kelas XII Multimedia SMK Negeri 1 Amuntai

\begin{tabular}{ccc}
\hline No & Kelas & Jumlah Slswa \\
\hline 1 & XII Multimedia 1 & 40 \\
2 & XII Multimedia 2 & 40 \\
\hline Jumah & & 80 \\
\hline
\end{tabular}

Sampel adalah bagian dari jumlah dan karakteristik yang dimiliki oleh populasi tersebut (Sugiyono, 2015:117). Sampel dalam penelitian ini adalah siswa yang dijadikan object penelitian setelah melakukan perhitungan dimana dalam penelitian ini menggunakan 66 sampel. Teknik yang dilakukan dalam pengambilan sampel ini menggunakan Proportionate Stratified Random Sampling di karenakan siswa yang dijadikan object penelitian bersifat yang tidak homogen dan berstrata secara proporsional.

Salah satu metode yang digunakan untuk menentukan jumlah sampel adalah menggunakan rumus Slovin (Sevilla et. al., 1960:182), dimana untuk menggunakan rumus ini, pertama ditentukan berapa batas toleransi kesalahan. Batas toleransi kesalahan ini dinyatakan dengan persentase. Semakin kecil toleransi kesalahan, semakin akurat sampel menggambarkan populasi. Pengambilan sampel dapat dilihat pada Tabel 2 sebagai berikut: 


\section{TEKNO Junal Teknologi Elektro dan Kejurvon}

http://journal2.um.ac.id/index.php/tekno | ISSN 1693-8739

Tabel 2. Pengambilan Sampel Menggunakan Proportionate Stratified Random Sampling

\begin{tabular}{cccc}
\hline No & Kelas & Jumlah Siswa & Sampel \\
\hline 1 & XII Multimedia 1 & 40 & $40 / 80 \times 66=33$ \\
2 & XII Multimedia 2 & 40 & $40 / 80 \times 66=33$ \\
\hline Total Sampel & & & 66 \\
\hline
\end{tabular}

Instrumen merupakan suatu alat yang digunakan untuk memperoleh data penelitian. Instrumen penelitian digunakan untuk mengukur nilai variabel yang diteliti. Dengan demikian jumlah instrumen penelitian tergantung pada jumlah variabel yang diteliti (Sugiyono, 2016: 133). Instrumen dalam penelitian ini berupa: (1) Angket RPP, (2) Angket Modul Digital, Lembar Penerapan Observasi, dan Hasil Belajar.

Jenis angket yang digunakan pada RPP dan modul digital adalah semi terbuka karena dapat memberikan data tidak hanya menjawab pertanyaan yang diberikan tetapi juga dapat memberikan saran dan komentar sebagai masukan untuk perbaikan RPP dan Modul Digital.angket Modul Digital

Penyusunan angket RPP dan Modul Digital digunakan untuk menilai RPP dan Modul Digital digunakan sebelum diterapkan dalam pembelajaran. Skala pengukuran yang digunakan pada angket ini menggunakan skala likert. Jawaban setiap instrumen yang menggunakan skala likert mempunyai gradasi dan sangat positif sampai sangat negatif, yang dijelaskan pada Tabel 3 (Sugiyono, 2014:93) sebanyak empat tingkat sebagai berikut:

Tabel 3. Skala Likert

\begin{tabular}{ll}
\hline Skala & Skor \\
\hline Sangat Setuju (SS) & 4 \\
Setuju (S) & 3 \\
Tidak Setuju (TS) & 2 \\
Sangat Tidak Stuju (STS) & 1 \\
\hline
\end{tabular}

Data angket yang terkumpul selanjutnya dihitung dengan analisis deskriptif yang diadaptasi dari (Akbar dan Sriwiyana 2010: 213). Persentase rumus analisis deskriptif dijelaskan pada persamaan 3.2.

$$
\begin{aligned}
& \mathrm{V}=\frac{\mathrm{TSEV}}{\mathrm{S}-\mathrm{max}} \times 100 \% \\
& \text { Keterangan: } \\
& \begin{array}{l}
\mathrm{=} \quad \text { Validitas } \\
\text { TSEV } \quad=\text { Total skor empirik validator } \\
\text { S-max } \quad=\text { Total skor maksimal }
\end{array}
\end{aligned}
$$

Pers (3.2) 


\section{TEKNO Jurnal Teknologi Elektro dan Kejuruan}

http://journal2.um.ac.id/index.php/tekno | ISSN 1693-8739

Dasar pengambilan keputusan untuk validitas angket menggunakan kriteria penilaian yang diadaptasi dari (Akbar dan Sriwiyana 2010: 212) dijelaskan pada Tabel 4.

Tabel 4. Kriteria Validitas

\begin{tabular}{ll}
\hline Tingkat Persentase & Tingkat Validitas \\
\hline $85,01 \%-100,00 \%$ & Sangat valid (dapat digunakan tanpa revisi) \\
$70,01 \%-85,00 \%$ & Cukup valid (dapat digunakan dengan revisi kecil) \\
$50,01 \%-70,00 \%$ & Kurang valid (tidak dapat digunakan, perlu revisi besar) \\
$01,00 \%-50,00 \%$ & Tidak valid (terlarang digunakan) \\
\hline
\end{tabular}

Hasil validasi RPP untuk Dosen dan Guru pengampu matapelajaran Desain Multimedia Interaktif serta hasil validasi Modul Digital untuk Ahli Materi dan Ahli Media dijelaskan pada Tabel 5.

Tabel 5. Hasil Uji Validitas Instrument Angket

\begin{tabular}{llll}
\hline Instrument & Total Butir Soal & Validitas & Keterangan \\
\hline RPP Kepsek & & 88,0 & Sangat Valid \\
RPP Guru & 21 & 85,7 & Sangat Valid \\
Ahli Media & 28 & 87,5 & Sangat Valid \\
Ahli Materi Guru & 48 & 88.0 & Sangat Valid \\
Ahli Materi dosen & 48 & 90,1 & Sangat Valid \\
\hline
\end{tabular}

Instrument lembar angket RPP diadaptasi dari Pedoman Penilaian RPP Mahasiswa KPL di Universitas Negeri Malang tahun 2015. Dalam pengambilan data melalui angket sebagai validator diberikan kepada Kepala Sekolah dan Guru Pengampu mata pelajaran Desain Multimedia Interaktif.

Hasil validasi RPP untuk Kepala Sekolah dapat diihat pada Tabel 7 dimana dari 21 butir item yang menggunakan skala likert pada Tabel 4.1 didapatkan total skor empirik validator (TSEV) adalah 95 yang selanjutnya dihitung menggunakan analisis deskriptif didapatkan validitas (V) sebesar 90,47\%. Setelah dikonsultasikan dengan kriteria validitas yang diadaptasi dari Akbar dan Sriwiyana, maka instrumen angket RPP untuk Kepala Sekolah memiliki tingkat validitas sangat valid (dapat digunakan tanpa revisi).

Tabel 6. Hasil Validasi RPP Kepala Sekolah

\begin{tabular}{llll}
\hline Jumlah butir soal & TSEV & V & Keterangan \\
\hline 21 & 95 & 90,4 & Sangat Valid \\
\hline
\end{tabular}

Hasil validasi RPP untuk Guru dapat dilihat pada Tabel 8 dimana dari 21 butir item yang menggunakan skala likert pada Tabel 4.1 didapatkan total skor empirik validator (TSEV) adalah 97 yang selanjutnya dihitung menggunakan analisis deskriptif didapatkan validitas (V) sebesar 92,38\%. Setelah dikonsultasikan dengan kriteria validitas yang diadaptasi dari Akbar dan

TEKNO Vol. 28 Issue 1, p61-77 | Jurusan Teknik Elektro, Universitas Negeri Malang, Indonesia | Maret 2018 Nur Amalianda, Wahyu Sakti G. Irianto, Heru Wahyu Herwanto | Hubungan penerapan metode pembelajaran... 


\section{TEKNO Jumal Teknologi Elektro dan Kejuruan}

http://journal2.um.ac.id/index.php/tekno | ISSN 1693-8739

Sriwiyana, maka instrumen angket RPP untuk Guru memiliki tingkat validitas sangat valid (dapat digunakan tanpa revisi).

Tabel 7. Hasil Validasi RPP Guru Matapelajaran.

\begin{tabular}{lcll}
\hline Jumlah butir soal & TSEV & V & Keterangan \\
\hline 21 & 97 & 92,38 & Sangat Valid \\
\hline
\end{tabular}

Hasil validasi Modul Praktikum untuk Ahli Materi (Guru) dapat dilihat pada Tabel 11 dimana dari 48 butir item yang menggunakan skala likert pada Tabel 4.1 didapatkan total skor empirik validator (TSEV) adalah 172 yang selanjutnya dihitung menggunakan analisis deskriptif didapatkan validitas (V) sebesar $89,50 \%$. Setelah dikonsultasikan dengan kriteria validitas yang diadaptasi dari Akbar dan Sriwiyana, maka instrumen angket Modul Praktikum untuk Ahli Materi (Guru) memiliki tingkat validitas sangat valid (dapat digunakan tanpa revisi).

Tabel 8. Hasil Validasi Ahli Materi Modul Digital Guru

\begin{tabular}{llll}
\hline Jumlah butir soal & TSEV & V & Keterangan \\
\hline 48 & 172 & 89,50 & Sangat Valid \\
\hline
\end{tabular}

Hasil validasi Modul Praktikum untuk Ahli Materi (Dosen) dapat dilihat pada Tabel 12 dimana dari 48 butir item yang menggunakan skala likert pada Tabel 4.1 didapatkan total skor empirik validator (TSEV) adalah 173 yang selanjutnya dihitung menggunakan analisis deskriptif didapatkan validitas (V) sebesar 90,01\%. Setelah dikonsultasikan dengan kriteria validitas yang diadaptasi dari Akbar dan Sriwiyana, maka instrumen angket Modul Praktikum untuk Ahli Materi (Dosen) memiliki tingkat validitas sangat valid (dapat digunakan tanpa revisi).

Tabel 9. Hasil Ahli Materi Validasi Modul Digital Dosen

\begin{tabular}{llll}
\hline Jumlah butir soal & TSEV & V & Keterangan \\
\hline 48 & 172 & 89,50 & Sangat Valid \\
\hline
\end{tabular}

Hasil validasi Modul Praktikum untuk Ahli Media dapat dilihat pada Tabel 3 dari 28 butir item yang menggunakan skala likert pada Tabel 4.1 didapatkan total skor empirik validator (TSEV) adalah 98 yang selanjutnya dihitung menggunakan analisis deskriptif didapatkan validitas (V)

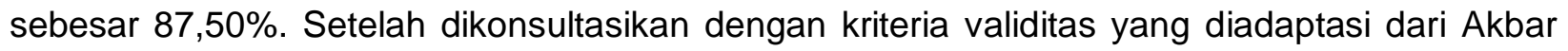
dan Sriwiyana, maka instrumen angket Modul Praktikum untuk Ahli Media memiliki tingkat validitas sangat valid (dapat digunakan tanpa revisi).

Tabel 10. Hasil Ahli Media Modul Digital

\begin{tabular}{llll}
\hline Jumlah butir soal & TSEV & V & Keterangan \\
\hline 28 & 98 & 87,50 & Sangat Valid \\
\hline
\end{tabular}

TEKNO Vol. 28 Issue 1, p61-77 | Jurusan Teknik Elektro, Universitas Negeri Malang, Indonesia | Maret 2018 Nur Amalianda, Wahyu Sakti G. Irianto, Heru Wahyu Herwanto | Hubungan penerapan metode pembelajaran... 


\section{TEKNO Jurnal Teknologi Elektro dan Kejuruan}

http://journal2.um.ac.id/index.php/tekno | ISSN 1693-8739

Instrumen yang digunakan dalam pengukuran penerapan metode pembelajaran project based learning berbasis GRASPS berupa lembar observasi yang diisi oleh observer. Lembar obsevasi ini dibuat berdasarkan beberapa indikator metode pembelajaran project based learning berbasis GRASPS, indikator disini menggunakan elemen yang ada pada GRASPS yaitu: (1) Goal, (2) Role, (3) Audience, (4) Situation, (5) Product, and (6) Standart. Dimana elemen tersebut diambil dari gagasan Wiggins and McTighe bernama "backward planning" atau "backward design" dalam bukunya "Understanding by Design".

Instrumen pengumpulan data dokumentasi yang digunakan dalam penelitian ini hasil nilai post-test siswa. Instrumen penelitian ini dibutuhkan untuk mengumpulkan data variabel hasil belajar siswa pada mata pelajaran produktif multimedia khususnya desain multimedia interaktif pada siswa kelas XII Multimedia SMK Negeri 1 Amuntai.

Tabel 11. Validitas

\begin{tabular}{llll}
\hline No & Rentang Nilai & Skor & Kriteria \\
\hline & & & \\
1. & $90-100$ & 4 & Sangat Baik \\
2. & $80-89$ & 3 & Baik \\
3. & $70-79$ & 2 & Kurang Baik \\
4. & $69 \leq$ & 2 & Sangat Tidak Baik \\
\hline
\end{tabular}

Instrumen dibuat untuk mendapatkan data yang valid dan layak untuk diteliti. Agar instrumen tepat maka instrumen membutuhkan pengujian. Instrumen dalam penelitian ini akan diujicobakan pada 14 siswa diluar sampel yang digunakan.

Validitas instrumen terbagi dalam validitas internal (validitas konstruk dan validitas isi) dan validitas eksternal atau validitas empiris. Validitas konstruk dapat dilakukan dengan menggunakan pendapat dari ahli yang kemudian diuji cobakan pada sampel darian populasi diambil. Sedangkan validasi isi dapat dilakukan dengan bantuan kisi - kisi atau matrik pengembangan instrumen.

Validitas yang dilakukan dalam penelitian ini adalah uji validitas dengan membandingkan isi instrumen dan kisi-kisi yang harus dimasukkan sebagai komponen instrumen serta validitas konstruk dengan cara mendiskusikan dengan ahli kemudian diujicobakan pada sampel uji coba diluar sampel penelitian. Perhitungan validitas item dalam penelitian ini menggunakan korelasi kendall's. Sebagaimana uji korelasi Spearman, uji korelasi kendall's tau digunakan untuk uji korelasi yang datanya berbentuk ordinal atau berjenjang (rangking) dan bebas distribusi, uji korelasi ini akan diuji dengan menggunakan SPSS 24.0 for Windows. Syarat bahwa item-item tersebut adalah valid adalah nilai korelasi ( $r$ hitung $\geq$ dengan $r$ tabel), $r$ tabel dapat dilihat dari tabel nilai-nilai $r$ kendall's tau atau tabel koefisien korelasi $(r)$ person.

Hasil uji validitas dapat dilihat pada Tabel 18 dengan jumlah 40 butir soal dinyatakan valid $100 \%$, maka semua butir soal dapat digunakan untuk selanjutnya diuji reliabilitas instrumennya. 


\section{TEKNO Junal Teknologi Elekrio dan Kejurvan}

http://journal2.um.ac.id/index.php/tekno | ISSN 1693-8739

Uji Realibilitas berfungsi untuk menyakinkan apakah instrumen yang dipakai dapat dipercaya untuk menggali data atau tidak. Reliabel artinya dapat dipercaya juga dapat diandalkan. Sehingga beberapa kali diulang pun hasilnya akan tetap sama (konsisten).

Metode yang digunakan dalam penelitian untuk mengukur reliabilitas angket media pembelajaran modul digital menggunakan rumus Alpha Cronbach (Suharsimi Arikunto, 2006: 178-196), tertera pada persamaan 3.4.

$$
\mathrm{r}_{11=}\left[\frac{k}{k-1}\right]\left[1-\frac{\sum \sigma_{b}^{2}}{\sigma_{t}^{2}}\right]
$$

Pers (3.4)

Keterangan :

$$
\begin{aligned}
& r_{11}=\text { Koefisien reliabilitas instrumen yang dicari } \\
& \mathrm{k} \quad=\text { Banyaknya butir pertanyaan atau banyaknya soal }
\end{aligned}
$$

$$
\begin{aligned}
\sum \sigma_{b}^{2} & =\text { Jumlah variansi skor butir soal ke-i } \\
\mathrm{i} & =1,2,3,4, \ldots \mathrm{n}
\end{aligned}
$$$$
\sigma_{t}^{2} \quad=\text { Variansi total }
$$

Dari hasil penghitungan dengan menggunakan SPSS 24.0 for Windows. Suatu instrumen dikatakan baik apabila koefesien korelasi untuk reliabilitasnya adalah lebih dari 0,55 . Jika nilai rhitung > 0, 55 maka disimpulkan soal tersebut reliabel.

Ringkasan data hasil uji reliabilitas dengan jumlah 40 butir soal valid diperoleh nilai Apha Croncbach's sebesar 0, 973 dapat dilihat pada Tabel 12.

Tabel 12. Hasil Uji Reliabilitas

\begin{tabular}{ll}
\hline Cronbach's Alpha & N of items \\
\hline .973 & 40 \\
\hline
\end{tabular}

Hasil penghitungan menggunakan software SPSS 24 for Windows dengan teknik analisis Reliability Koefisien Alpha Cronbach's didapatkan nilai $r_{\text {hitung }}$ sebesar 0,973. Jika nilai $r_{\text {hitung }}>0$, 55 maka dapat dikatakan instrumen tersebut reliabel.

Sedangkan untuk mengetahui tinggi rendahnya reliabilitas instrumen digunakan kategori sebagai berikut (Hadi, 1999:216):

1. $0,800-1,000$ : sangat tinggi

2. $0,600-0,799 \quad$ : tinggi

3. $0,400-0,599$ : cukup

4. $0,200-0,399$ : rendah

5. $0,000-0,199$ : sangat rendah 


\section{TEKNO Junal Teknologi Elekrro dan Kejuruan}

http://journal2.um.ac.id/index.php/tekno | ISSN 1693-8739

Tingkat kesukaran soal digunakan untuk mengetahui apakah butir soal tersebut terlalu sulit, sedang atau terlalu mudah yang di jelaskan pada Tabel 13. Penentuan kriteria tingkat kesukaran soal tertera pada persamaan 3.5 sebagai berikut (Arikunto, 2006: 175).

$P=\frac{B}{J s}$

Pers (3.5)

Keterangan:

$\mathrm{P} \quad=$ Indeks kesukaran

$\mathrm{B}$ = Banyak siswa yang menjawab soal dengan benar

$\mathrm{Js}=$ Jumlah seluruh siswa

Tabel 13. Kriteria Tingkat Kesukaran

\begin{tabular}{ll}
\hline Nilai $P$ & Keterangan \\
\hline $0,00-0,30$ & Sukar \\
$0,31-0,70$ & Sedang \\
$0,71-1,00$ & Mudah \\
\hline
\end{tabular}

Hasil perhitungan dengan rumus Arikunto (2006) didapatkan nilai $P_{\text {hitung }}$ (indeks kesukaran) Selanjutnya $\mathrm{P}_{\text {hitung }}$ dikonsultasikan dengan $\mathrm{P}_{\text {tabel }}$ maka didapatkan soal dengan taraf sukar ada 3 item, soal dengan taraf sedang ada 22 item dan soal dengan taraf mudah ada 15 item.

Daya beda butir soal berfungsi untuk melihat sampai dimana butir soal tersebut mampu membedakan antara siswa kelompok atas dan siswa kelompok bawah dijelaskan pada Tabel 14.

Tabel 14. Kriteria Daya Beda

\begin{tabular}{ll}
\hline Nilai D & Keterangan \\
\hline $0,00-0,20$ & Jelek \\
$0,21-0,40$ & Cukup \\
$0,41-0,70$ & Baik \\
$0,71-1,00$ & Baik Sekali \\
\hline
\end{tabular}

Rumus yang digunakan dalam menguji daya beda yang digunakan tertera pada persamaan 3.6 Berikut (Arikunto, 2006:176)

$D=\frac{B_{A}}{J_{A}}-\frac{B_{B}}{J_{B}}$

Pers (3.6)

Keterangan:

$\mathrm{D}$ = Daya beda soal

$\mathrm{B}_{\mathrm{A}}=$ Total jawaban benar siswa kelompok atas

$\mathrm{B}_{\mathrm{B}}=$ Total jawaban benar siswa kelompok bawah

$\mathrm{J}_{\mathrm{A}}=$ Banyaknya siswa kelompok atas

$J_{B} \quad=$ Banyaknya siswa kelompok bawah 


\section{TEKNO Jurnal Teknologi Elektro dan Kejuruan}

http://journal2.um.ac.id/index.php/tekno | ISSN 1693-8739

Pengumpulan data penelitian ini dilakukan di SMK Negeri 1 Amuntai dilakukan dengan langkah - langkah sebagai berikut:

1. Pada tahap persiapan melakukan penyusunan instrumen penelitian berupa: (a) menyusun angket RPP dan angket Modul Praktikum, (b) menyusun RPP yang selanjutnya di validasi oleh Dosen dan Guru pengampu matapelajaran Desain Multimedia Interaktif, (c) membuat Modul Praktikum yang selanjutnya di validasi oleh ahli media dan ahli materi, (d) menyusun soal tes kemampuan siswa yaitu posttest yang selanjutnya diuji coba pada siswa diluar sampel, (e) hasil uji coba soal posttest dilakukan uji instrumen diantaranya: uji validitas butir soal, uji reliabilitas, uji tingkat kesukaran, dan uji daya beda soal.

2. Melaksanakan proses pembelajaran dengan menerapkan metode belajar sesuai RPP yang sudah di validasi oleh Dosen dan Guru pengampu matapelajaran Desain Multimedia Interaktif dan membagikan Modul Praktikum sebagai sumber belajar siswa yang sudah di validasi oleh Ahli Materi dan Ahli Media. Selanjutnya di akhir pembelajaran siswa diberikan posttest pada masing-masing kelas dengan bobot yang sama.

3. Mengolah seluruh data yang telah diperoleh (hasil belajar) untuk dilakukan uji normalitas, uji homogenitas dan uji hipotesis

4. Analisis data digunakan untuk memberikan makna terhadap data yang telah dikumpulkan dari sampel, metode analisis data dari jenis penelitian korelasioanal ini adalah menggunakan statistik parametris. Statistik parametris ini digunakan untuk menguji parameter populasi melalui statistik, atau menguji ukuran populasi melalui data sampel (Sugiyono, 2016: 210-211).

Uji prasyarat analisis data diperlukan untuk mengetahui apakah analisis data untuk pengujian hipotesis dapat dilanjutkan atau tidak. Sebelum diuraikan cara menguji hipotesis penelitian korelasi terlebih dahulu akan dijelaskan syarat yang harus dipenuhi agar pengujian dapat dilakukan, yakni:

a. Data harus Normal atau Uji Normalitas

b. Data harus linear atau Uji Linearitas

Kedua persyaratan itu mutlak dilakukan dalam penelitian korelasi atau hubungan. Bisa juga ditambahkan dengan Uji homogenitas. Namun dalam penelitian korelasi, uji homogenitas bukan syarat penting. Umumnya pengujian kehomogenan digunakan pada pengujian hipotesis penelitian untuk ujibeda.

\section{a. Normalitas}

Uji normalitas data bertujuan untuk mengetahui apakah sampel yang diambil berasal dari populasi berdistribusi normal atau tidak. Data yang baik adalah data yang memiliki distribusi normal. Uji normalitas data dilakukan dengan menggunakan test Kormogorov Smirnov, dasar pengambilan keputusan dilakukan berdasarkan probabilitas sebagai berikut: 


\section{TEKNO Jurnal Teknologi Elektro dan Kejuruan}

http://journal2.um.ac.id/index.php/tekno | ISSN 1693-8739

1) Jika nilai probabilitas (Sig) $>0,05$, maka data berdistribusi normal.

2) Jika nilai probabilitas (Sig) $\leq 0.05$, maka data tidak berdistribusi normal.

b. Linearitas

Uji lineraritas hubungan dilakukan untuk membuktikan apakah variabel bebas mempunyai hubungan yang linear dengan variabel terikat. Linearitas menunjukkan variasi hubungan linear dari kedua variabel yang diuji. Untuk pengujian linieritas SPSS menggunakan Tes for Linearity. Dengan menggunakan taraf siginifikasi 5\% maka ketentuan mengenai linearitas variabel bebas dan terikat dengan bantuan software SPSS 24 for Windows diindikasikan dengan:

1) Nilai Sig. atau probabilitas lebih besar dari 0.05 (Sig. $>0.05)$ mengindikasi tidak ada hubungan linear (non linear) antara kedua variabel yang diuji.

2) Nilai Sig. atau probabilitas lebih kecil dari 0.05 (Sig. < 0.05) mengindikasikan ada hubungan linear antara kedua variabel yang diuji.

\section{c. Uji Homogenitas}

Uji homogenitas bertujuan untuk mencari tahu apakah dari beberapa kelompok data penelitian memiliki varians yang sama atau tidak. Perhitungan uji homogenitas menggunakan software SPSS adalah dengan Uji Levene statistics. Dengan menggunakan taraf signifikansi $5 \%$ maka ketentuan mengenai homogenitas data diindikasikan dengan:

1) Nilai Sig. atau probabilitas lebih besar dari 0.05 (Sig.> 0.05) yang artinya data penelitian homogen.

2) Nilai Sig. atau probabilitas lebih kecil dari 0.05 (Sig.<0.05) yang artinya data penelitian tidak homogen.

\section{Uji Hipotesis}

Data kuantitatif yang diperoleh berupa hubungan skor test akhir (posttest) antara metode pembelajaran Project Based Learning berbasis GRASPS berbantu modul digital dengan hasil belajar. Signifikansi hubungan hasil belajar siswa akan dianalisis dengan menggunakan bantuan software SPSS 24 for Windows dengan teknik korelasi product moment. Uji Koefisien Korelasi Product Moment adalah uji statistik untuk menguji 2 variabel yang berdata rasio ataupun data kuantitatif yang berisi angka riil yaitu data sesungguhnya yang diambil langsung dari angka asli.

Syarat lain untuk uji korelasi product moment adalah data berdistribusi normal. Untuk mengetahui terdapat hubungan atau tidak dapat dilihat dari nilai signifikansi dan seberapa kuat hubungan tersebut dapat dilihat dari nilai koefisien korelasi atau $r$.

\section{a. Pengambilan keputusan}

1) Jika Sig di atas 0,05 maka Ho diterima, Maka tidak terdapat hubungan yang signifikan

2) Jika Sig di bawah 0,05 maka Ho ditolak, maka terdapat hubungan yang signifikan

Setelah melalui pengujian hipotesis dan hasilnya signifikan, maka untuk menentukan keeratan hubungan bisa digunakan kriteria Guilford, yaitu : 


\section{TEKNO Junal Teknologi Elektro dan Kejuruan}

http://journal2.um.ac.id/index.php/tekno | ISSN 1693-8739

Tabel 15. Kriteria keeratan tingkat hubungan

\begin{tabular}{ll}
\hline Interval Koefisien & Tingkat Hubungan \\
\hline Korelasi Sangat Rendah & $0,0-0,9$ \\
Korelasi Rendah & $0,2-0,39$ \\
Korelasi Sedang & $0,4-0,59$ \\
Korelasi Kuat & $0,6-0,9$ \\
Korelasi Sangat Kuat & $0,8-1,0$ \\
\hline
\end{tabular}

\section{Uji Regresi Linear Sederhana}

Uji Regresi linier sederhana adalah hubungan secara linear antara satu variabel independen $(\mathrm{X})$ dengan variabel dependen $(\mathrm{Y})$. Analisis ini untuk mengetahui arah hubungan antara variabel independen dengan variabel dependen apakah positif atau negatif dan untuk memprediksi nilai dari variabel dependen apabila nilai variabel independen mengalami kenaikan atau penurunan.

Kriteria Pengujian:

a. Jika nilai Sig. atau probabilitas lebih kecil dari $0.05($ Sig.< 0.05$)$ yang artinya terdapat korelasi/hubungan yang positif dan signifikan.

b. Jika nilai Sig. atau probabilitas lebih besar dari 0.05 (Sig.> 0.05) yang artinya tidak terdapat korelasi/hubungan yang positif dan signifikan.

\section{Hasil}

Hasil uji normalitas menggunakan software SPSS 24 for Windows dengan teknik analisis One Sample Kolmogorov-Smirnov Test didapatkan hasil yang dijelaskan pada Tabel 16.

Tabel 16. Hasil Uji Normalitas penerapan Metode (X) dan Hasil belajar (Y)

\begin{tabular}{llll}
\hline Variabel & Signifikansi & P-Standar & Ket \\
\hline $\mathrm{X}$ & 0,58 & 0,05 & Normal \\
$\mathrm{Y}$ & 0,77 & 0,05 & Normal \\
\hline
\end{tabular}

Diketahui pada Tabel 15 Nilai Asymp. Sig. Variabel X adalah 0,058 > 0,05 maka berdasarkan kriteria pengujian data variabel $X$ berdistribusi normal. Sedangkan Nilai Asymp. Sig. Variabel $Y$ adalah $0,077>0,05$ maka berdasarkan kriteria pengujian data variabel $Y$ berdistribusi normal.

\section{a. Uji Linearitas}

Hasil uji linearitas menggunakan software SPSS 24 for Windows g dijelaskan pada Tabel 26

Tabel 17. Hasil Uji Linearitas Metode belajar (X) dan Hasil Belajar (Y)

\begin{tabular}{llll}
\hline Variabel & $F$ & signifikansi & Keterangan \\
\hline$X^{\star} Y$ & 136,799 & 0,000 & Linear \\
\hline
\end{tabular}

TEKNO Vol. 28 Issue 1, p61-77 | Jurusan Teknik Elektro, Universitas Negeri Malang, Indonesia | Maret 2018

Nur Amalianda, Wahyu Sakti G. Irianto, Heru Wahyu Herwanto | Hubungan penerapan metode pembelajaran... 


\section{TEKNO Junal Teknologi Elektro dan Kejurvon}

http://journal2.um.ac.id/index.php/tekno | ISSN 1693-8739

Diketahui pada Tabel 16Nilai Sig. Deviation from Linearity $0,000<0,05$ maka berdasarkan kriteria pengujian mengindikasikan ada hubungan linier antara kedua variabel yang diuji.

\section{b. Uji Homogenitas}

Hasil uji normalitas menggunakan software SPSS 24 for Windows dengan Uji Levene Statistic didapatkan hasil yang dijelaskan pada Tabel 17

Tabel 18. Hasil Uji Homogenitas Hasil Belajar

\begin{tabular}{lcccc}
\hline Hasil_Belajar Levene Statistic & df1 & df2 & Sig. & Keterangan \\
\hline 1.860 & 13 & 50 & .059 & Homogen \\
\hline
\end{tabular}

Diketahui pada Tabel 17 Nilai Sig. 0,059 > 0,05 berdasarkan kriteria pengujiannya maka data penelitian dikatakan homogen.

\section{Uji Hipotesis}

Hasil uji hipotesis menggunakan software SPSS 24 for Windows dengan teknik analisis korelasi Product Moment didapatkan hasil yang dijelaskan pada Tabel 18

Tabel 19. Korelasi Metode Belajar (X) dan Hasil Belajar (Y)

\begin{tabular}{llll}
\hline Variabel & Pearson Corelation & signifikansi & Ket \\
\hline$X^{\star} Y$ & 0,919 & 0,000 & Signifikan \\
\hline
\end{tabular}

Diketahui pada Tabel 18 diatas nilai Sig. 0,000 0,05 berdasarkan kriteria pengujian maka terdapat korelasi/hubungan antara variabel $\mathrm{X}$ dan variabel $\mathrm{Y}$, dan melihat dari tabel keeratan hubungan dapat diketahui nilai korelasi 0.919 termasuk kedalam "korelasi sangat kuat".

\section{PEMBAHASAN}

Uji hipotesis disini menggunakan Korelasi Product Moment yang merupakan salah satu bentuk statistik parametris karena menguji data pada skala interval atau rasio. Sebelum kita mengolah data untuk uji hipotesis menggunakan Korelasi Product Moment ada beberapa persyaratan untuk dapat menggunakan Korelasi Product Moment, yaitu :

1) Sampel diambil dengan teknik random (acak)

2) Data yang akan diuji harus homogen

3) Data yang akan diuji juga harus berdistribusi normal

4) Data yang akan diuji bersifat linier

Jika data penelitian yang dibuat sudah interval atau rasio maka langkah selanjutnya melakukan Uji Normalitas, Uji Homogenitas dan Uji Linearitas terlebih dahulu. 


\section{TEKNO Jumal Teknologi Elektro dan Kejuruan}

http://journal2.um.ac.id/index.php/tekno | ISSN 1693-8739

\section{Uji Prasyarat Analisis Data}

1. Uji Normalitas

Hasil uji normalitas menggunakan software SPSS 24 for Windows dengan teknik analisis One Sample Kolmogorov-Smirnov Test. Data yang baik adalah data yang memiliki distribusi normal, dasar pengambilan keputusan dilakukan berdasarkan probabilitas sebagai berikut:

1) Jika nilai probabilitas (Sig) $>0,05$, maka data berdistribusi normal.

2) Jika nilai probabilitas (Sig) $\leq 0.05$, maka data tidak berdistribusi normal.

Sehingga data diambil kesimpulan bahwa data penerapan metode Project Based Learning berbasis GRASPS berbantuan Modul Digital kelompok $X$ adalah $0.058 \geq 0.05$ maka data berdistribusi dengan normal dikarenakan nilai probabilitas signifikansi data yang didapat $>0$. 05. Sedangkan hasil uji normalitas data hasil belajar yang merupakan data kelompok y adalah $0.077 \geq 0.05$ maka data tersebut berdistribusi dengan normal dikarenakan nilai probabilitas signifikansi data yang didapat $>0.05$.

Berdasarkan hal tersebut maka sampel yang diambil dari populasi pada masing-masing kelas/kelompok merupakan data yang baik. Karena data yang baik adalah data yang memiliki distribusi normal

\section{Uji Linearitas}

Hasil uji homogenitas menggunakan software SPSS 24 for Windows dengan teknik analisis Test for Linearity. Dengan menggunakan taraf siginifikasi 5\% maka ketentuan mengenai linearitas variabel bebas dan terikat dengan bantuan software SPSS 24 for Windows diindikasikan dengan:

1) Nilai Sig. atau probabilitas lebih besar dari 0.05 (Sig. > 0.05) mengindikasi tidak ada hubungan linear (nonlinear) antara kedua variabel yang diuji.

2) Nilai Sig. atau probabilitas lebih kecil dari 0.05 (Sig. < 0.05) mengindikasikan ada hubungan linear antara kedua variabel yang diuji.

Hasil data yang didapatkan dengan nilai taraf signfikansi 5\% adalah $0.000<0.05$ Maka, dinyatakan kriteria pengujian mengindikasikan bahwa ada hubungan yang linear antar variabel penerapan metode Project Based Learning berbasis GRASPS berbantuan Modul (X) dan Hasil Belajar (Y).

\section{Uji Homogenitas}

Hasil uji homogenitas menggunakan software SPSS 24 for Windows dengan teknik analisis One-Way Anova .Dengan menggunakan taraf signifikansi 5\% maka ketentuan mengenai homogenitas data diindikasikan dengan:

1) Nilai Sig. atau probabilitas lebih besar dari 0.05 (Sig.> 0.05) yang artinya data penelitian homogen.

2) Nilai Sig. atau probabilitas lebih kecil dari $0.05($ Sig.< 0.05$)$ yang artinya data penelitian tidak homogen. 


\section{TEKNO Jurnal Teknologi Elektro dan Kejuruan}

http://journal2.um.ac.id/index.php/tekno | ISSN 1693-8739

Setelah dilakukan uji homogenitas data hasil belajar siswa didapatkan nilai Probabilitas (Sig.) adalah 0.059. Berdasarkan hal tersebut maka dapat diambil kesimpulan bahwa varian data hasil belajar siswa tersebut adalah homogen karena nilai Sig. (0.977) $\geq 0.05$ sesuai kriteria pengujian yang telah dirumuskan.

\section{Kesimpulan dan Saran}

Berdasarkan uraian hasil penelitian tentang Hubungan Penerapan Metode Pembelajaran Project Based Learning Berbasis Grasps dan Penggunaan Media Pembelajaran Modul Digital Terhadap Hasil Belajar Siswa Pada Mata Pelajaran Produktif Multimedia Di Smkn 1 Amuntai dapat ditarik beberapa kesimpulan antara lain :

Hasil yang diperoleh pada penelitian ini menyatakan terdapat hubungan signifikan antara penerapan metode Project Based Learning berbasis GRASPS berbantu modul digital dengan hasil belajar

Berdasarkan uraian hasil penelitian tentang Hubungan Penerapan Metode Pembelajaran Project Based Learning Berbasis Grasps berbantu Modul Digital dengan Hasil Belajar Siswa Pada Mata Pelajaran Produktif Multimedia Di Smkn 1 Amuntai. Adapun saran yang bisa disampaikan:

1. Saran bagi guru agar penelitian ini dijadikan salah satu alternatif dalam memilih variasi pembelajaran Multimedia Interaktif untuk meningkatkan hasil belajar siswa.

2. Bagi siswa dapat memiliki andil yang besar dalam proses pembelajaran dengan ikut berperan aktif selama proses pembelajaran, sehingga siswa dapat meningkatkan hasil belajar demi tercapainya tujuan pembelajaran. Siswa yang belum menunjukan partisipasi dalam kegiatan pembelajaran disarankan untuk meningkatkan aktivitas pada saat pembelajaran dan lebih mempersiapkan diri sebelum proses pembelajaran di kelas dimulai.

Bagi peneliti selanjutnya dapat digunakan sebagai salah satu sumber data untuk mengembangkan penelitian berdasarkan faktor lain seperti: variabel yang berbeda sebagai contoh mengukur minat atau kreatifitas siswa, jumlah sampel yang lebih banyak, tempat yang berbeda seperti sekolah atau matapelajaran yang lainnya, serta desain pembelajaran yang lebih tepat.

\section{Daftar Rujukan}

Amri, S. 2013. Pengembangan \& Model Pembelajaran dalam Kurikulum 2013. Jakarta: PT Prestasi Pustakaraya.

Akbar, S dan Sriwiyana. 2010. Pengembangan Kurikulum dan Pembelajaran IImu Pengetahuan Sosial (IPS). Yogyakarta: Cipta Media.

Arikunto, S. 2006. Prosedur Penelitian Suatu Pendekatan Praktik. Jakarta: Rineka Cipta.

Hadi, S. 1999. Metodologi Research II. Yogyakarta: Andi Offset.

Sugiyono. 2015. Metode Penelitian Kuantitatif Kualitatif Dan R\&D.

Bandung: Alfabeta.

TEKNO Vol. 28 Issue 1, p61-77 | Jurusan Teknik Elektro, Universitas Negeri Malang, Indonesia | Maret 2018 Nur Amalianda, Wahyu Sakti G. Irianto, Heru Wahyu Herwanto | Hubungan penerapan metode pembelajaran... 


\section{TEKNO Jumal Teknologi Elekrto dan Kejuruan}

http://journal2.um.ac.id/index.php/tekno | ISSN 1693-8739

Sugiyono. 2016. Metode Penelitian Pendidikan: Pendekatan Kuantitaif, Kualitatif, dan R\&D. Bandung: Alfabeta.

Sevilla, C. G.et. al. 1960. Research Methods. Quezon City: Rex Printing Company.

Suyatno. 2009. Menjelajah Pembelajaran Inovatif. Sidoarjo: Masmedia Buana Pustaka 